\title{
The perception of family caregivers regarding the changes that occur after the diagnosis of dementia
}

Luciana Maria Santos Cesário'

Isabelle Patriciá Freitas Soares Chariglione'

\section{Abstract}

Objectives: to identify the perceptions of family caregivers regarding the changes that occurred in the family after an elderly relative received a diagnosis of dementia, measuring the changes in the level of burden and analyzing the discourse of such caregivers. Method: the research was conducted through an interview and sociodemographic questionnaire, in addition to the application of a scale that measures caregiver burden, the Zarit Burden Interview. These procedures were applied in two stages, in the multidisciplinary reception of a geriatric clinic, and after three months of care. For the qualitative analysis, the $I R a M u T e Q$ software was used, where, in the first stage, the results were as follows: in the Descending Hierarchical Classification (DHC) four classes were identified: Time (25.00\%), Knowledge (33.00\%), Consequences and Causes (19.40\%); In the Word Cloud (WC), the word 'No" prevailed. In the second stage, DHC presented six classes, Current Time (13.70\%), General Causes (15.70\%), Future Time (13.70\%), Actions (17.60\%), Consequences $(23.50 \%)$ and Immediate Causes (15.70\%). The WC continued to refer most frequently to the word 'No'. For quantitative analyzes, the SPSS software was used. Results: in most cases, the profile of caregivers was women $(75.00 \%)$, wives $(62.00 \%)$, primary caregivers $(87.50 \%)$, and the elderly (60-75 years). The assessment of burden was moderate to severe $(75.00 \%)$. Conclusion: caring for a relative with a diagnosis of dementia has direct implications for family caregivers, especially family caregivers facing the aging process. The demands of caring modify the family routine and greatly increase the burden of caregivers.
Keywords: User Embracement. Caregivers. Dementia. Family. 


\section{INTRODUCTION}

A high prevalence of chronic diseases is inherent to the elderly population is. One example of these are syndromes of dementia, and there is a tendency for the number of elderly people suffering from this condition to increase. Population aging and increased life expectancy lead, as a consequence, to the emergence of chronic-degenerative diseases, notably dementias ${ }^{1-3}$. According to the Diagnostic and Statistical Manual of Mental Disorders (DSM-5), major neurocognitive disorder is a clinical syndrome, which includes the deterioration of the cognitive domains, behavioral changes and impairment in one or more of the following areas: attention; executive functioning; learning and memory; language; motor perception; social cognition. It also interferes with social and occupational functioning. This situation inevitably results in a reliance on care, and therefore requires caregivers.

Alzheimer-type dementia and other diseases that have a major psychosocial impact are considered family-related diseases ${ }^{1,5,6}$, especially syndromes of dementia, considered the 21st century epidemic, as they require prolonged and specific care ${ }^{2}$.

The development of profiles of dementia has implications for the life and social support network of patients. In Brazil, care for elderly people with some form of major neurocognitive disorder is generally provided by families, with little or no institutional support or even specific policies for this purpose ${ }^{8}$.

Studies have demonstrated the social impact on the health and well-being of formal and informal caregivers ${ }^{5,9,10}$. It is they who immediately and directly suffer the negative consequences of having to deal with a relative with Alzheimer's disease ${ }^{11}$.

It is important to highlight that the construction of the care process continues throughout the life experience of the family caregiver and is directed by the reality of the family, as well as by the guidance provided by the multiprofessional health team and support groups and associations ${ }^{1,12}$.

In Brazil, data from epidemiological-type research prevails. Studies related to the financial costs of elderly people with dementia are still incipient in gerontology literature ${ }^{13-15}$.
According to Ministry of Health Ordinance no. 2,528 (2006) which approved the National Policy on the Health of the Elderly Person (PNSPI) and revoked Ordinance no. 1,395 (1999), the caregiver is any person, whether a family member or not, paid or otherwise, formal or informal, who provides care to an elderly person who depends on assistance in their activities of daily living, such as eating, personal hygiene, medication, being accompanied to health services, bank services or pharmacies, among others ${ }^{16}$.

Another way to interpret the role of the caregiver was provided by the Ministry of Health in the Basic Care Handbook, which states that he or she is a family member or non-family member who provides care to a dependent elderly person. The caregiver's tasks involves accompanying daily activities, such as aid with eating, personal hygiene, routine medication, among others; assisting in the recovery and quality of life of that person ${ }^{17}$.

Therefore, elderly people with dementia syndromes need permanent care and usually receive this care from their relatives. The construction of the caring process is directed by the reality of the family and the internal and external resources to provide care. Understanding the resources of caregivers can help to design psychoeducational interventions and changes in health policies. The purpose of the present study was to illustrate the perceptions of family caregivers after an elderly relative was diagnosed with dementia, measuring the changes in the level of burden and analyzing the discourse of these family members.

\section{METHOD}

A qualitative study featuring a non-intentional convenience sample, based on the demand met, was carried out between September and December 2017, taking into account the difficulty of random selection. The sample initially consisted of 19 caregivers receiving care in the geriatric service of the Multidisciplinary Center for the Elderly (MCE) of the Hospital Universitário de Brasília (HUB).

It is worth noting that around 20 elderly people enter the MCE per month, and there was therefore an expectation that the sample would include the study of at least 50 such individuals. However, the 
months evaluated were atypical due to holidays and internal activities, leading to the closure of the outpatient clinics.

It is also worth noting that, as this is a qualitative study, there was no minimum expectation for the sample, as the validity of the research is not based on the size of the sample, as in a quantitative study, but rather on the depth with which the study is performed. Trivinõs ${ }^{18}$ states that in qualitative research random resources can be employed to fix the sample. In this case, one can intentionally decide the size of the sample, considering a series of conditions, such as subjects that are essential to clarify the subject in focus, from the point of view of the researcher, including ease of meeting people, the time individuals have available for interview and so on.

For the inclusion criteria, we selected family caregivers with a minimum age of eighteen, male or female, literate, with the following levels of kinship: spouse, son or daughter, brother or sister, grandson or granddaughter, nephew or niece, son or daughterin-law. We excluded formal caregivers hired by the family and those who cared for relatives without the diagnosis of dementia.

After the inclusion and exclusion criteria were applied, and including after the beginning of the study, four elderly patients withdrew for the following reasons: one patient, who described herself as a relative (because of her proximity to the elderly person) was actually a formal caregiver (exclusion criterion); in one patient cognitive decline, rather than dementia, was observed on a follow-up appointment; one patient was institutionalized, and was unable to continue care or continue as the objective of this study; one family member gave up and appeared unmotivated for further meetings.

In the end eight family caregivers were evaluated, with a median age of 67 years (33-75 years) who cared for elderly persons with a median age of 73 years (67-84 years), selected at the reception unit of the multidisciplinary care center, which consists of physicians and medical residents, physiotherapists, odontologists, pharmacists and pharmaceutical residents and social workers, the latter being responsible for receiving the elderly within the service and who were solely responsible for the procedures that made up the methodological process.

The initial care in the reception unit is carried out once a week in the morning, where each professional carries out an initial approach specific to the area for around 30 to 50 minutes. After the consultations, a multidisciplinary team meeting is held to discuss the cases and create the therapeutic care plan.

The materials used were divided into three, as described below: a) socio-demographic evaluation, which aimed to evaluate the socioeconomic and demographic reality in which the family member and the elderly person are inserted, consisting of 21 objective items relating to the dimensions of family, financial situation and support network; b) an interview about the perception of the caregiver, which is composed of five open questions that allowed the free expression of the interviewees in the dimensions of diagnosis, difficulties and perspectives; c) the Zarit Burden Interview scale.

The Brazilian version of the Zarit Scale was used to evaluate caregiver burden. This is a standardized and validated instrument used in the study of the impact of mental and physical illness on informal caregivers. It allows the assessment of the burden of the informal caregiver and includes information about health, social life, personal life, financial situation, emotional situation and type of relationship. The scale is multidimensional, and evaluates the factors of impact of delivering care, interpersonal relationship, expectations of caring, and perception of self-efficacy. Scores range from zero to 88 , and the higher the score, the greater the burden of the family caregiver ${ }^{14}$.

The procedures were divided into two types: methodological procedures and data analysis.

The methodological procedures involved three steps:

1 - Selection, carried out during the social service operating hours, in the reception unit of the geriatric clinic. A Free and Informed Consent Form was read and signed by all the caregivers, once they had received information about the objectives, content and duration of the interview, the conditions of 
participation in the two phases of data collection and the rights of the participants.

2 - Evaluation in the reception unit, where the following instruments were applied: a sociodemographic assessment, in order to identify the profile of the family caregiver; the Zarit Scale, to measure the informal caregiver's level of burden; and an interview recorded with a digital device and transcribed in its entirety by the researcher, to identify the perception of the family caregiver about the reality of caring for an elderly relative with dementia. This phase had an average duration of 40 minutes for each participant and was carried out individually. Pre-intervention was performed from September to December 2017. The instruments were applied by the researcher, a social worker of the geriatrics department/MCE/HUB.

3 - Evaluation following reception, in which the following instruments were applied to the eight participants who remained in the survey: the Zarit Scale and the interview recorded in a digital device and transcribed in its entirety by the researcher, to identify the perception of the caregiver. The researcher carried out this second evaluation in the geriatric service/MCE/HUB on days and at times previously scheduled with the participants. The postreception phase was carried from February to March 2018. By that time, the participants had already returned for at least one medical consultation after reception and at least one orientation provided by the social service. The intervention of the social service aims to get to know other relatives whether included or not in the context of elderly care, to welcome them into the service and to provide information about how to deal with a family member diagnosed with dementia, what risk situations should be avoided, what measures should be taken from a legal point of view, such as for example, the prohibition and cessation of the elderly from driving a vehicle, and also on the activities available in the geriatrics service.

The data analysis procedures were performed for the quantitative and qualitative data. The most recent version of the Statistical Package for the Social Sciences (SPSS) was used for the quantitative data, taking into account the fundamental statistical assumptions for the correct use of the various statistical techniques, which were the normal distribution of the variables (Kolmogorov Smirnov) and homoscedasticity (Levene's Test). All analyzes were performed with a level of significance of $p<0.05$.

Some descriptive measures were generated for the characterization of the sample and, as it involves non-parametric distribution with the objective of comparing whether the measurements of position of two phases would be equal in cases where the samples are dependent, Wilcoxon's test was used. This analysis was used to evaluate the Zarit Scale, comparing the two phases in which these tests were applied to the caregivers.

For the qualitative data, the interviews about caregiver's perception were analyzed using the IRaMuTeQ software (Interface de $\mathrm{R}$ pour les Analyses Multidimensionnelles de Textes et de Questionnaires), which allows statistical analyzes on the textual corpus to be made. The software used is licensed and free, and enables different types of analysis of textual data. With this analysis, it was possible to explore the interviews, as they were recorded and literally transcribed. Each interview generated a text and the set of these texts constituted the corpus of the analysis. The software requires that the raw textual data be formatted in the manner read by the program (txt), following which the analysis is processed. It was first used in Brazil in 2013 and the area of health has since appropriated this tool ${ }^{19}$ which uses Bardin ${ }^{20}$ for content analysis.

The present study was approved by the Ethics Research Committee of the Universidade Católica de Brasília (Approval No 2.233.802/2017) and the School of Medicine of the Universidade de Brasília (Approval No 2.306.606/2017), which also approved the Free and Informed Consent Form. The methodological procedures described were only performed after submission and acceptance by the referent Committees.

\section{RESULTS}

The data presented will always relate to the caregivers who were the objects of this study. The quantitative data will be presented for the characterization of the sample (Table 1) and for the comparison of the measures of the Zarit Scale of care burden. 
Table 1. Sociodemographic description of family caregivers of the Multidisciplinary Center for the Elderly of the Hospital Universitário de Brasília. Brasília, Distrito Federal, 2017.

\begin{tabular}{|c|c|c|}
\hline Variables & $\mathrm{n}$ & $\%$ \\
\hline \multicolumn{3}{|l|}{ Kinship } \\
\hline Spouse & 5 & 62.50 \\
\hline Son/daughter & 3 & 37.50 \\
\hline \multicolumn{3}{|l|}{ Income } \\
\hline No income & 1 & 12.50 \\
\hline From one to four times minimum wage & 6 & 75.00 \\
\hline Over five times minimum wage & 1 & 12.50 \\
\hline \multicolumn{3}{|l|}{ Financial collaboration } \\
\hline Yes & 6 & 75.00 \\
\hline No & 2 & 25.00 \\
\hline \multicolumn{3}{|l|}{ Marital status } \\
\hline Married & 8 & 100.00 \\
\hline \multicolumn{3}{|l|}{ Children } \\
\hline Yes & 8 & 100.00 \\
\hline \multicolumn{3}{|l|}{ Age } \\
\hline From 30 to 59 & 2 & 25.00 \\
\hline From 60 to 75 & 6 & 75.00 \\
\hline \multicolumn{3}{|l|}{ Gender } \\
\hline Male & 2 & 25.00 \\
\hline Female & 6 & 75.00 \\
\hline \multicolumn{3}{|l|}{ Burden } \\
\hline Yes & 6 & 75.00 \\
\hline No & 2 & 25.00 \\
\hline
\end{tabular}

The profile, based on social assessment, shows the majority of the care is provided by spouses $(62.50 \%)$, with children $(100.00 \%)$, who were elderly $(65.00 \%)$, female $(75.00 \%)$ and who claimed to suffer burden through this activity $(75.00 \%)$. It is noteworthy that of these eight caregivers, four, all of whom were elderly, became MCE patients, a husband and three wives, with symptoms of anxiety and depression. In terms of kinship and marital status, daughters and wives were the most frequently responsible for providing care.

The information about experiencing burden in Table 1 can be corroborated by the analysis of the level of burden at the reception and post-reception phase. After the Wilcoxon test, there was no significant difference between the measurements at reception and two months later, with $p=0.40$. However, there was a tendency for the median caregiver burden to increase from 26.00 (19-48) to 28.00 (14-58).

Regarding changes in the level of caregiver burden, based on the Zarit Scale scores of mild from 0 to 20, moderate from 21 to 40, moderate to severe from 41 to 60 and severe from 61 to 88, the caregivers scored from 19 to 48 and 14 to 58 in the first and second stages of the survey, respectively. In the first application of the scale, two sons or daughters had mild burden, four wives and one husband had moderate burden, with the husband experiencing less burden, and one daughter had moderate to severe burden.

In the post-reception application of the Zarit Scale, the two sons or daughters with mild burden obtained the same classification, however, the daughter's score increased (23 points) while the son's score decreased (14 points). The classifications of the four wives and the husband, who had moderate burden in the first phase, changed as follows: one remained moderate, although with a higher score (33 points), two increased from moderate to severe (41 and 43 points), the burden of one wife changed to mild (15 points), while the husband remained 
at mild, though with a lower score (19 points). The other daughter continued at the moderate to severe level with a higher score (58 points).

As the qualitative classifications relate to the perception of the familiar caregiver, based on the reality of study, the textual corpus was analyzed by the IRaMuTeQ method in both stages (reception and post-reception) using three methods, a) Descending Hierarchical Classification (DHC), from a dendrogram of word classes; b) Word cloud, which is a lexical analysis as a function of frequency; c) textual corpus (exemplifying the discourse of daughters, wives and one husband), for a greater understanding of the discussion about the changes that occur following multiprofessional interventions.

\section{Reception stage}

The DHC shows words that are similar to each other. Figure 1 is divided into four classes, where class four, categorized as "getting to know", is the basis for the formation of other classes, covering $33.30 \%$ of the total content analyzed.

The DHC analysis presented four classes, categorized here as Time (25,00\%), Knowledge (33,30\%), Consequences (22,20\%) and Causes (19,40\%).

The word cloud (Figure 2) made it possible to identify the keyword. The most frequent word: "No" was compatible with the analysis of similitude. This type of analysis makes it possible to use statistical calculations on qualitative data, the texts ${ }^{21}$.

\begin{tabular}{|c|c|c|c|}
\hline Class 1 & Class 4 & Class 3 & Class 2 \\
\hline $25.00 \%$ & $33.30 \%$ & $22.20 \%$ & $19.40 \%$ \\
\hline to go out & to get to know & so & to tell \\
\hline house & to understand & like this & even \\
\hline to leave & love & thing & better \\
\hline one time & much & house & change \\
\hline future & think & family & all \\
\hline difficult & to know & to arrive & to take \\
\hline to change & to care for & to give & worried \\
\hline disease & more & people & to give \\
\hline normal & to feel & to stay & because \\
\hline vear & when & day & now \\
\hline year & to speak & now & like this \\
\hline more & to suffer & like & \\
\hline to stay & affection & change & \\
\hline because & thing & & \\
\hline
\end{tabular}

Figure 1. Dendogram of the words of the family caregivers of the Multidisciplinary Center for the Elderly of the Hospital Universitário de Brasília. Brasília, DF, 2018. 


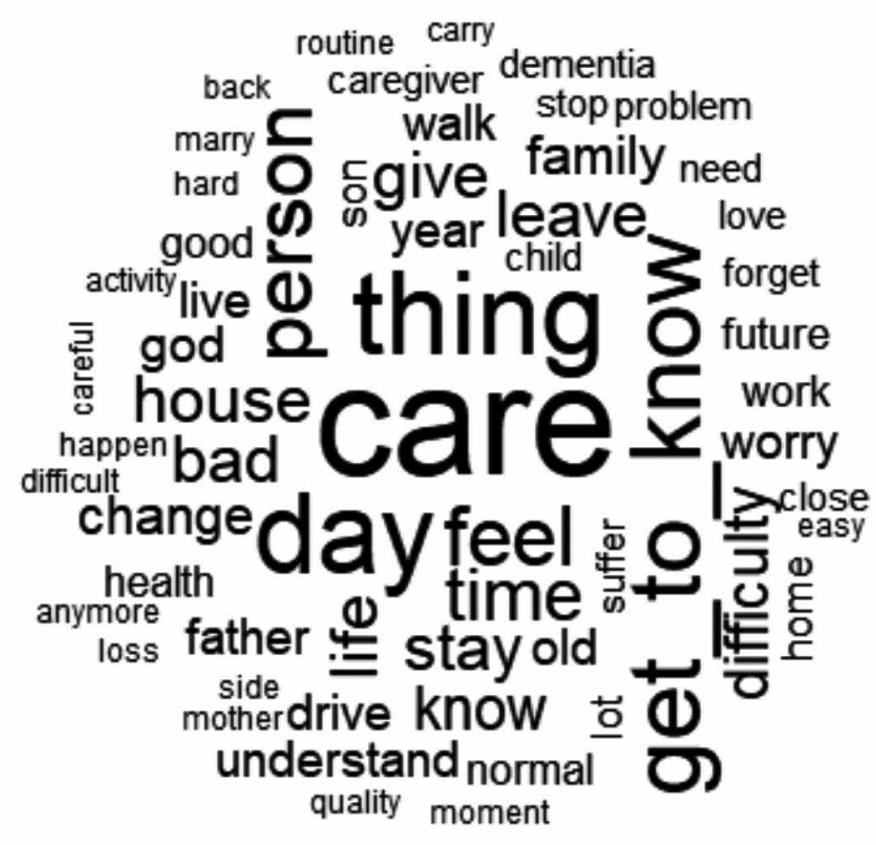

Figure 2. Frequency of words analyzed in the content of the family caregivers of the Multidisciplinary Center for the Elderly of the Hospital Universitário de Brasília. Brasília, DF, 2018.

The textual corpus that can exemplify the preintervention moment are presented below:

"I don't think I'm a good caregiver, I learned from my mother not to be subtle. The hardest thing is, I have this duty every day, I have no day off. For example, I retired a year ago, my life got worse than when I worked, because I did not leave the house anymore" (Daughter, 61)

"I feel it's something I have to do for him, even if he was not my husband. Because, if it were me, wouldn't he? The hardest part is that I work every day, but it's not difficult for me yet. The family routine, in fact I think we relied on him for many things and then we stopped relying. That was the change and the family was surprised to see how much he was forgetting things and lost his autonomy" (Wife, 65).

"I think it's even a pleasure to know, I say this because on one hand we're sad, but God gives me health and I have enough strength to have enough knowledge to provide quality care, the care offers quality of life. So far there have been no changes, because I take on the burden. Because we did not give up on letting him do things with our help, but letting him take the lead, so there hasn't been much change, just the burden on me" (Wife, 69).

The difficulties of coping with the existing changes for these elderly caregivers can clearly be perceived. Even if such changes are denied.

\section{Post-Reception Stage}

The corpus of the DHC was divided into two groups and four subgroups. In this second stage, the word dementia was highlighted $(23.50 \%)$, as can be observed in Figure 3. 


\begin{tabular}{|c|c|c|c|c|c|}
\hline \multirow{2}{*}{$\begin{array}{l}\text { Class } 2 \\
15.70 \%\end{array}$} & Class 4 & Class 3 & Class 1 & Class 6 & Class 5 \\
\hline & $17.60 \%$ & $13.70 \%$ & $13.70 \%$ & $15.70 \%$ & $23.50 \%$ \\
\hline because & to bring & to change & food & To & dementia \\
\hline to care for & to take & to leave & to know & remember & now \\
\hline all & people & to want & to give & always & dad \\
\hline house & difficulty & to go out & time & also & to speak \\
\hline more & when & possible & routine & to ask & to happen \\
\hline change & to like & to need & get & new & to know \\
\hline here & to need & life & worse & to & until \\
\hline $\begin{array}{l}\text { to leave } \\
\text { always }\end{array}$ & $\begin{array}{l}\text { son } \\
\text { medical }\end{array}$ & same & to stay & understand & person \\
\hline person & wellbeing & nothing & no & here & there \\
\hline \multirow{2}{*}{$\begin{array}{l}\text { like } \\
\text { already }\end{array}$} & to change & only & to think & to forget & to take away \\
\hline & house & all & & & to reply \\
\hline thing & thing & to like & God & to speak & day \\
\hline to like & to go out & difficulty & day & doctor & already \\
\hline to feel & routine & to feel & so & to stay & to forget \\
\hline to tell & today & to tell & more & to know & to lose \\
\hline \multirow{6}{*}{ inside } & to accompany & to accompany & to feel & no & family \\
\hline & situation & situation & to tell & to reply & much \\
\hline & to occur & next & to take away & next & \\
\hline & & to occur & today & to occur & \\
\hline & & inside & much & one time & \\
\hline & & time & & when & \\
\hline
\end{tabular}

Figure 3. Dendrogram of the classes and frequency of words of the family caregivers of the Multidisciplinary Center for the Elderly of the Hospital Universitário de Brasília. Brasília, DF, 2018.

The analysis by DHC presents six classes that are categorized here as: Current moment $(13.70 \%)$, General causes $(15.70 \%)$, Future $(13.70 \%)$, Actions $(17.60 \%)$, Consequences $23.50 \%)$ and Immediate causes $(15.70 \%)$.
In the word cloud, the word "No" remains constant in frequency, followed by much, difficult, caring, dementia and family, according to Figure 4. 


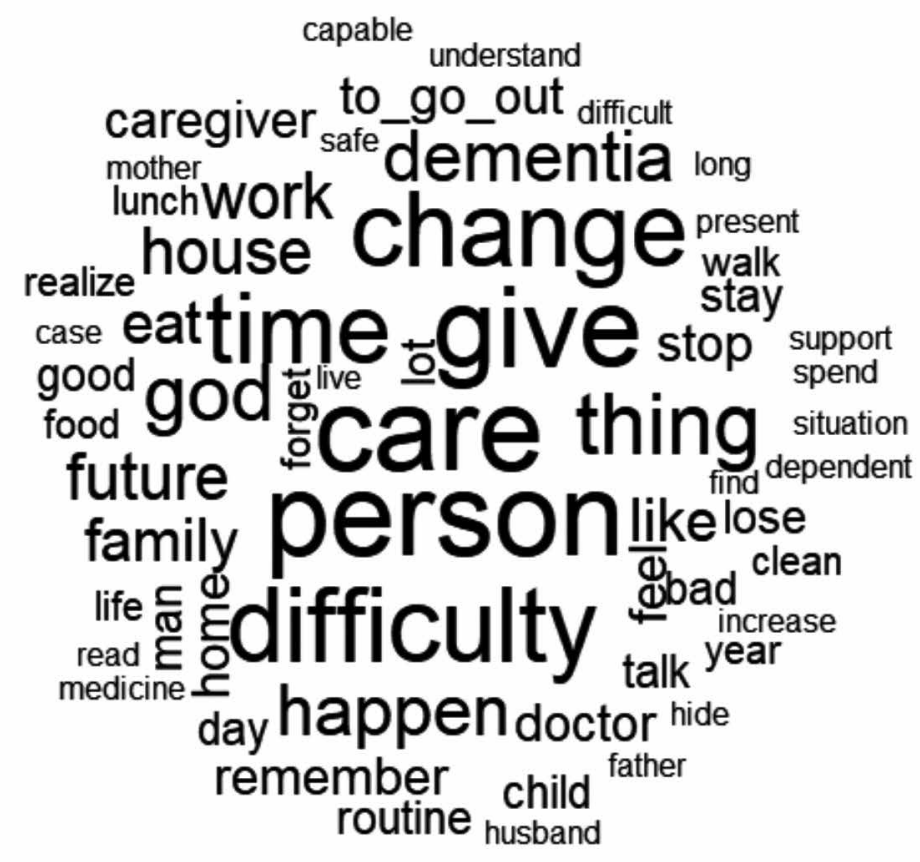

Figure 4. Frequency of words analyzed in the content of caregivers of the Multidisciplinary Center for the Elderly of the Hospital Universitário de Brasília. Brasília, DF, 2018.

To characterize the change in the perception of the family caregivers, in the face of the reality of caring, some excerpts from the post-reception phase are described below.

"As a caregiver I try to do my best, there is not much change. The only change is that when we go to Unaí, we have to take him.” (Daughter, 37)

"I would like him to be well enough to go out, we had a lot of freedom to go out, he drove, I did not drive, we didn't stay at home, he was very independent but we're not anymore. The changes aren't slight, the routine of the family has changed, we just take him to the doctor, get his medicine when he needs it, but not much has changed" (Wife, 69)

“The hardest thing, I don't think, I don't find it hard to do what I do for her, I do it with pleasure for her to be well, I don't find anything difficult. I give her food, I do whatever she needs. The change I had was to stop working, even though I was recovering from surgery, and there was the normal concern for the children and the husband for their mother. So there was no change, the change that there was I think is because every family suffers a lot with it." (Husband, 71)
Thus, in the perspective of these relatives, the context in which they are inserted is characterized by changes, and it can be observed that they contradict each other at all times, and these data are discussed below.

\section{DISCUSSION}

Although significant differences in the measurements of the Zarit Scale between the reception and post-reception phases were not found, the data of the present study revealed the presence of burden in $75.00 \%$ of the relatives.

The results observed in this study are very similar to previous studies, such as that by Enrique Ramon, ${ }^{22}$ which found that the daily care of a family member with dementia generates changes in the family, as well as burdening the main caregiver, who is usually a daughter or a wife.

In terms of the profile of the elderly caregiver found in the present study, of the sample of eight, six were women (two daughters and four wives), similar to the results of other studies. This finding is 
related to the issue of gender in the function of care, which historically and even today has been attributed to women, with daughters and wives assuming the status of primary caregivers, which seems intrinsic to the gender issue in the performance of the role of caring ${ }^{23,24}$. Family caregivers carry out their role in a context characterized by personal change, both in relation to the person receiving care (those with dementia suffer cognitive and behavior alterations and experience changes in social roles) and in the social and cultural context ${ }^{25}$.

In the present study moderate to moderate severe burden was observed in five family members when the Zarit Scale was applied. This finding points to the considerable level of effort required from caregivers who provide help in the self-care and routine household activities of elderly persons with dementia ${ }^{26,27}$.

It was found that elderly caregivers at the time of the study (one husband and three wives) were diagnosed with depression and anxiety, a fact that reveals frailty in the caregiver profile ${ }^{27,28}$. This reality of the elderly caregiver has become increasingly common and influences quality of life, acquired burden, as well as the changes resulting from aging ${ }^{29-31}$. With the stressors of this age group, it was found that the burden of the task of caring involves physical, psychological, social and financial problems.

When attempting to understand how the family member perceives themselves as caregivers and the difficulties they face in this role, it was verified that their reality is characterized by the change in the context in which they are inserted ${ }^{25}$.

Their reports confirmed the degree of difficulty in the unexpected situations of the behavior of the elderly with dementia, which must be confronted by the family caregivers. The challenge of caring needs to be perceived by caregivers ${ }^{32}$.

In the present study it was possible to understand that, despite the difficulties in dealing with an elderly person with dementia, the family members perceive themselves as caregivers with a range of feelings, with apprehension and with physical, emotional and financial burden. However, they face such a condition with affection, spirituality and in some cases, with the support of family members.

In addition, elderly people experiencing the aging process and being caregivers of their relatives experience worry over recognizing their own aging and need for care ${ }^{31,33}$. It is assumed here that the caregiver and the family require psychosocial support in order to receive suggestions for coping with the situation. In the present study, the importance of a gerontology outpatient clinic which, in welcoming the patient and the family, is considering a long-term therapeutic plan, was clear.

The importance of the present study is based on the fact that it provides continued investigation into a subject of great current importance and urgency, notably burden and the fact that the elderly are taking care of fellow elderly persons. Its limitations are related to the reduced number of family caregivers of the elderly, the short time gap in measurement following reception, and the lack of comparison with the group of family caregivers who had been receiving care at the MCE for a longer period (six months, one year), verifying if the time factor is important within the multidisciplinary intervention variable.

\section{CONCLUSION}

The data from the present study show that caring for a relative diagnosed with dementia has direct implications for family caregivers. Faced with this reality of aging, which demands care for the elderly, it is important to rethink and expand the progress of the Unified Health System, through the creation of Reference Centers for Health Care for the Elderly. Services related to diagnosis, treatment, follow-up care of patients, guidance for family members and caregivers, with a multidisciplinary care team, should systematically support the needs of patients with dementia and family members, not only in outpatient and hospital settings, but also at home.

The family member, while presenting burden, is perceived as the primary caregiver and often assumes this condition alone, and is unprepared for this sudden changes of roles, in other words where children take care of parents. 
Due to these facts it is important to carry out studies that investigate the profile of family caregivers and the implications of this care, especially in the expanding scenario of elderly caregivers, to understand the phenomenon as it affects their reality, in order to provide theoretical support for the formulation of public policies that guarantee a network of support to these caregivers.

\section{REFERENCES}

1. Machado JCB. Doença de Alzheimer. In: Freitas EV, Xavier FA. Tratado de Geriatria e Gerontologia. Rio de Janeiro: Guanabara Koogan; 2000.

2. Burlá C, Camarano AA, Kanso S, Fernandes D, Nunes R. Panorama prospectivo das demências no Brasil: um enfoque demográfico. Ciênc Saúde Colet [Internet]. 2013 [acesso em 11 abr. 2018];18(10):2949-56. Disponível em: http://www. scielo.br/scielo.php?script $=$ sci_arttext\&pid=S141381232013001000019\&lng=pt

3. Baker DJ, Petersen RC. Cellular senescence in brain aging and neurodegenerative diseases: evidence and perspectives. J Clin Invest. [Internet]. 2018 [acesso em 19 mar. 2018];128(4):1208-16. Disponível em: https:// www.jci.org/articles/view/95145

4. American Psychiatric Association. Diagnostic and statistical manual of mental disorders. 5th ed. Washington, DC: American Psychiatric Press; 2013.

5. Cerquera CAM, Granados LFJ, Buitrago MAM. Sobrecarga en cuidadores de pacientes con demencia tipo Alzheimer. Psychol Av Discip. 2012;6(1):35-45.

6. Cornelia RK. Emotional experience in patients with advanced Alzheimer's disease from the perspective of families, professional caregivers, physicians, and scientists. Aging Ment Health [Internet]. 2018 [acesso em 19 mar. 2018];22(3):316-22. Disponível em: https://www.ncbi.nlm.nih.gov/pubmed/27936862

7. Rabins PV, Rovner BW, Rummans T, Schneider LS, Tariot PN. Guideline watch: practice guideline for the treatment of patients with Alzheimer's Disease and other dementias. Washington, DC: American Psychiatric Press; 2014.

8. Camarano AA. Política de cuidados para a população idosa: necessidades, contradições e resistências. In: $1^{\circ}$ Seminário internacional sobre políticas de cuidado de longa duração para pessoas idosas no Brasil; 22-23 nov. 2015; Brasília. Brasília, DF: OPAS/OMS; 2015.

\section{ACKNOWLEDGEMENTS}

The Multidisciplinary Center for the Elderly (MCE) of the Universidade de Brasília, Universidade de Brasília (UnB) professor Dayde Lane Mendonça da Silva, and Universidade Católica de Brasília (UCB) professors Gislane Ferreira de Melo, Alexander Hochdorn and Henrique Salmazo da Silva.

9. Lopes LO, Cachioni M. Cuidadores familiares de idosos com doença de Alzheimer em uma intervenção psicoeducacional. Rev Bras Geriatr Gerontol [Internet]. 2013 [acesso em 10 abr. 2018];16(3):443-60. Disponível em: http://www.scielo.br/scielo.php?script=sci_ arttext\&pid=S1809-98232013000300004\&lng=en

10. Folle AD, Shimizu HE, Naves JOS. Social representation of Alzheimer's disease for family caregivers: stressful and rewarding. Rev Esc Enferm USP. 2016;50(1):79-85.

11. Tomomitsu MRSV, Perracini MR, Neri AL. Fatores associados à satisfação com a vida em idosos cuidadores e não cuidadores. Ciênc Saúde Colet [Internet]. 2014 [acesso em 10 abr. 2018];19(8):3429-40. Disponível em: http://www.scielo.br/scielo.php?script=sci_ arttext\&pid=S1413-81232014000803429\&lng=en

12. Ferreira DPC, Coriolano MGWS, Lins CCSA. The perspective of caregivers of people with Parkinson's: an integrative review. Rev Bras Geriatr Gerontol [Internet]. 2017 [acesso em 28 mar. 2018];20(1):99-109. Disponível em: http://www.scielo.br/scielo.php?script=sci arttext\&pid=S1809-98232017000100099\&lng=en

13. Smith R, Drennan V, Mackenzie A, Greenwood N. The impact of befriending and peer support on family carers of people living with dementia: a mixed methods study. Arch Gerontol Geriatr. 2018;76:188-95.

14. Scazufca M, Cerqueira ATAR, Menezes PR, Prince M, Vallada HP, Miyazaki MCOS, et al. Investigações epidemiológicas sobre demência nos países em desenvolvimento. Rev Saúde Pública [Internet]. 2002 [acesso em 10 abr. 2018];36(6):773-8. Disponível em: http://www.scielo.br/scielo.php?script $=$ sci_ arttext\&pid=S0034-89102002000700018\&lng=en

15. Lopes MA, Bottino CMC. Prevalência de demência em diversas regiões do mundo: análise dos estudos epidemiológicos de 1994 a 2000. Arq Neuropsiquiatr [Internet]. 2002 [acesso em 10 abr. 2018];60(1):61-9. Disponível em: http://www. scielo.br/scielo.php?script $=$ sci_arttext\&pid=S0004282X2002000100012\&lng=en 
16. Brasil. Ministério da Saúde. Portaria no . 2.528, de 19 de outubro de 2006. Aprova a Política Nacional de Saúde da Pessoa Idosa. Diário Oficial da União. 20 out. 2006; Seção 1.

17. Brasil. Ministério da Saúde. Envelhecimento e saúde da pessoa idosa. Brasília, DF: MS; 2006. (Cadernos de Atenção Básica, n. 19); (Série A. Normas e Manuais Técnicos).

18. Triviños ANS. Introdução à pesquisa em ciências sociais: a pesquisa qualitativa em educação. São Paulo: Atlas; 2008.

19. Camargo BV, Justo AM. IRaMuTeQ: um software gratuito para análise de dados textuais. Temas Psicol [internet]. 2013 [acesso em 20 mar. 2015];21(2):513-8. Disponível em: http://pepsic.bvsalud.org/pdf/tp/ v21n2/v21n2a16.pdf

20. Bardin L. Análise de conteúdo. Lisboa: Edições $70 ; 1975$.

21. Lahlou S. Text mining methods: an answer to Chartier and Meunier. Pap Soc Representat [Internet]. 2012 [acesso em 20 dez. 2015];20(38):1-7. Disponível em: http://www.psych.lse.ac.uk/psr/PSR2011/20_39.pdf

22. Ramón-Arbués E, Martínez-Abadía B, MartínGómez Susana. Factores determinantes de la sobrecarga del cuidador. Estudio de las diferencias de gênero. Aten Prim. 2017;49(5):308-9.

23. Cardoso CCL, Rosalini MHP, Pereira MTML. O Cuidar na concepção dos cuidadores: um estudo com familiares de doentes crônicos em duas unidades de saúde da família de São Carlos-SP. Serv Soc Rev. 2010;13(1):24-42.

24. Faleiros VP. Desafio de cuidar em Serviço Social: uma perspectiva crítica. Rev Katálysis [Internet]. 2013 [acesso em 19 mar. 2018];16(esp):83-91. Disponível em: http://dx.doi.org/10.1590/S141449802013000300006

25. Moreno-Cámara S, Palomino-Moral PA, MoralFernández L, Frias-Osuna A, Del-Pino-Casado R. Problemas en el proceso de adaptación a los cambios en personas cuidadoras familiares de mayores con demência. Gac Sanit. 2016;30(3):201-7.

26. Custodio N, Lira D, Herrera-Pérez E, Prado LN, Parodi $\mathrm{J}$, Guevara-Silva E, et al. Informal caregiver burden in middle-income countries Results from Memory Centers in Lima - Peru. Dement Neuropsychol [Internet]. 2014 [acesso em 24 abr. 2018];8(4):376-83. Disponível em: http://www.scielo.br/scielo.php?script=sci_arttext\&pid $=$ S1980-57642014000400376

27. Leite BS, Camacho ACLF, Joaquim FL, Gurgel JL, Lima TR, Queiroz RS. Vulnerabilidade de cuidadores de idosos com demência: estudo descritivo transversal. Rev Bras Enferm. 2017;70(4):682-8.

28. Caldeira RB, Neri AL, Batistoni SST, Cachioni M. Variáveis associadas à satisfação com a vida em cuidadores idosos de parentes também idosos cronicamente doentes e dependentes. Rev Bras Geriatr Gerontol [Internet]. 2017 [acesso em 31 mar. 2018];20(4):502-15. Disponível em: http://www. scielo.br/scielo.php?script $=$ sci_arttext\&pid=S1809$98232017000400502 \& \operatorname{lng}=$ pt

29. Muniz EA, Freitas CASL, Oliveira EN, Lacerda MR. Grau de sobrecarga dos cuidadores de idosos atendidos em domicílio pela Estratégia Saúde da Família. Saúde Debate [Internet]. 2016 [acesso em 31 mar. 2018];40(110):172-82. Disponível em: http://www.scielo.br/scielo.php?script $=$ sci_ arttext\&pid=S0103-11042016000300172\&lng=en

30. Rabelo DF, Neri AL. Tipos de configuração familiar e condições de saúde física e psicológica em idosos. Cad Saúde Pública [Internet]. 2015 [acesso em 31 mar. 2018];31(4):874-84. Disponível em: http://www. scielo.br/scielo.php?script $=$ sci_arttext\&pid=S0102311X2015000400874\&lng=en

31. Bom F, Sá S, Cardoso R. Overload in caregivers of the elderly. J Nurs UFPE online [Internet]. 2016 [acesso em 05 abr. 2018];11(1):160-4. Disponível em: https://periodicos.ufpe.br/revistas/ revistaenfermagem/article/view/11889

32. Cordeiro FDP, Sales CMW, Accioly LCCS. A perspectiva do cuidador da pessoa com Parkinson: revisão integrativa. Rev Bras Geriatr Gerontol. [Internet]. 2017 [acesso em 05 abr. 2018];20(1):99109. Disponível em: http://www.scielo.br/ scielo.php?script=sci_arttext\&pid=S180998232017000100099\&lng=en

33. McLaughlin D, Hasson F, Kernohan WG, Waldron M, McLaughlin M, Cochrane B, et al. Living and coping with Parkinson's disease: perceptions of informal carers. Palliat Med [Internet]. 2011 [acesso em 22 ago. 2015];25(2):177-82. Disponível em: http:// www.ncbi.nlm.nih.gov/pubmed/20952448 